\title{
EFL Students' Perceptions Toward Online English Learning During the Covid-19 Outbreak
}

\author{
Albiansyah ${ }^{1}$, Didin Nuruddin Hidayat ${ }^{1}$ and Rino Dedi Aringga ${ }^{1}$ \\ ${ }^{1}$ Universitas Islam Negeri Syarif Hidayatullah Jakarta, Indonesia \\ (albiaansyah@gmail.com)
}

\begin{abstract}
The present study aims at investigating English Foreign Language Students' perceptions toward online English learning at a private vocational school, Sekolah Menengah Kejuruan Bina Informatika Bintaro. In order to answer the research question, this study occupied descriptive qualitative research. The data were collected through questionnaires which were distributed to students. The participants of this study were 54 vocational high school students on 2020/2021 academic year who attended online English learning in the second semester. The samples were chosen by implementing purposive sampling technique. The results of the perception of most participants in the study expressed their support for the conduct of online English learning during the Covid-19 pandemic and agreed with the ease of accessibility. However, the study revealed some disagreement in terms of ease of use of the tools, English learning material understanding, and interaction. Further, the results of the research showed $60 \%$ of students stated that online English learning was unattractive compared to face-to-face learning, $27 \%$ said it was still interesting, and the rest were hesitant. Furthermore, it is hoped that English teachers use more suitable platforms when teaching English in online learning, so that students will be more interested in learning English online and will gain optimal learning outcomes.
\end{abstract}

Keywords: EFL students; perceptions; online English learning; Covid-19.

The global Covid-19 pandemic has influenced on many facets of life including the education (Stambough et al., 2020). Many countries in the world have closed their education activities both at schools and universities to prevent the transmission of Covid-19. Social distance believed to break the chain of transmission of
Covid-19 (Ong et al., 2020).

The COVID-19 pandemic or the influx of Corona virus into Indonesia has transformed the learning process of schools in most parts of Indonesia into Distance Learning or Learning from Home, or School from Home. As a result, learning methods that originally relied on lectures and physical 
interactions changed drastically to online. As Zhafira, et al. (2020) states that online learning is conducted by almost every educational institution to break the chain of spread of viruses and maintain the safety and security of students and educators. This condition requires residents including students and educators to stay at home, work, worship and study at home (Jamaluddin et al., 2020; Mesran et al., 2020; Sadikin \& Hamidah, 2020)

Such conditions of course require educational institutions to be more innovative in their teaching practices. One form of innovation is to do learning online or online. The Ministry of Education and Culture replied by releasing several Circular Letters on the prevention and treatment of Covid-19. First, Circular Letter No. 2 of 2020 on Covid-19 prevention and recovery in the Kemendikbud. Second, Circular Letter No. 3 of 2020 in the Education Unit on the Prevention of Covid-19. Third, Circular Letter No. 4 of 2020 concerning the Implementation of Education Policy in the Emergency Era of Coronavirus Disease (Covid-19) Outbreak, which provides guidance on how to study and teach from home, among other items (Arifa, 2020; Maris, 2020).

With this appeal, the learning process is carried out from the comfort of one's own home with the use of internet technology and media. Online learning simultaneously began to be applied at the elementary school level to high school even from kindergarten to college, since the middle or end of March 2020. In its application, distance learning is still extended until a time that cannot be determined definitively. Distance Learning itself according to Puspitasari and Islam (2016) is often associated with the term self-learning. The development of the concept of selflearning in the field of distance learning is a consequence of one of the characteristics of distance learning that demands higher self-learning skills than the form of faceto-face education.
Various reactions arose when distance learning policy was rolled out and implemented. Not only from the parents of the students, but also from educators and students. Because distance learning is a new thing for most Indonesians, the change in teaching methods from which was entirely done offline, then suddenly all educational institutions run the learning process online, no doubt makes many parties curious and curious. Research conducted by A.N, Sobron, et al. (2019) explains some of the advantages of online learning where they state that distance learning has an important aspect than face-toface learning that is safer because it reduces the impact of physical bullying and makes students dare to express opinions, questions, or answers online without worrying about negative responses of others. He also expands the learning community and teachers can more easily find and determine the right learning rhythm for students. The efficiency of time and cost in online learning is also an advantage, where educators and students can have learning anywhere and anytime. Students don't have to spend hours studying in class. Lesson materials can be accessed by students with the sophistication of technology, so that students can download and learn at any time without being limited in space and time.

Perception itself has been widely researched by many parties. One of them is Harisah and Masiming (2008) which explains that in general experts argue that the occurrence of perception is influenced by factors such as experience, background knowledge, physical background, social, and culture. Another opinion was asked by Rahmad (2003) that Perception is a person's perception of an item, occurrence, or piece of knowledge based on his or her life experience. Thus, it can also be said that perception is the result of one's mind from a particular situation (Tarmiji et al., 2016). Suwarto and Fajri (2018) stated that the nature of perception as something related to symptoms and experiences. Perception also can be formed through the human sensory 
organ, by seeing, hearing, touching, tasting, or experiencing (Muzakky \& Albiansyah, 2021). The more experience and knowledge in a person, the more and stronger the perception (Albiansyah \& Hardiyanti, 2021). In addition to science and experience, perception is also influenced by needs and psychological factors. Thus, one's perception of education is different from each other. As stated by Suwarto and Fajri (2018) that the perception of each person can be different, then the perception of students about SFH during the Covid-19 pandemic era needs to be reviewed.

Some previous studies show peoples' perceptions toward online learning during covid-19 outbreak. Lutfhiah (2020) did a qualitative research. It aimed to find out perceptions of the students' parents. She claimed that the Covid-19 pandemic has a huge effect on the world of education when asked about parents' views of online learning during the pandemic. Satrianingrum \& Prasetyo (2021) conducted qualitative case study on teachers' perception toward online learning during Covid-19 pandemic. They revealed various impacts and challenges faced in carrying out the online learning at home. The teacher's perception of the impact felt on the student is availability of inadequate facilities and infrastructure, differences in atmosphere when learning class by studying at home, which affects the motivation of students and the tendency of online learning styles is visual and written.

In this study, the researchers tried to analyze the perceptions of students toward online English learning during the Covid-19 pandemic. Since there is not study conducted in seeking the English foreign language learner's perception during the Covid-19 pandemic in the level of vocational high school, then it will the novelty of this research. This is important since the result of this study would help the educators to know how to evaluate online learning especially online English learning regarding to achieve students' optimal learning outcomes.-different from the preceding studies which tried to prove parents and teachers' perception of the online learning.

\section{Method}

It is descriptive qualitative research. It is intended to find out how is the EFL learners' perceptions of English online learning in the Covid-19 pandemic at Vocational High School. The participants in this study were chosen through a purposive sampling procedure, where a carefully selected group, and the best group was selected as research respondents with careful consideration. The researcher selected participants who had experience which was similar to the focus of the research (Dornyei, 2007). The participants involved were ten second-semester students at Bina Informatika vocational high school, which consists of 54 participants. They aged 15 to 16 years old. Pseudonyms were used in this study to maintain the students' confidentiality. To collect the data, researcher used questionnaire. A series of questionnaires which contain 15 questions and focus on the teaching material or mode, student interaction, platform used by the teacher, and learning atmosphere that determines the perceptions of students for particular purposes in knowledge of English online learning. Mayang, et., al (2017) note that questionnaires are fairly simple to execute, so that methods are often functioned. The students' responses to each item's choices have been changed to a percentage to look for which option is protruding along the other options. In analyzing students' perceptions, the dominant choices were then considered as the most informative feedback to be considered (Albiansyah \& Minkhatunnakhriyah, 2021). In analyzing the data, researcher used the theory of Miles, Hubarman \& Saldana (2014). It included some activities, such as by displaying, reducing and concluding or verifying the data. Through the data reduction the researchers focused on the data that analyzed. It can be easy for the researchers to continues the collecting the data. While in data display the researchers presented the data into design that 
was done in form of short statement, charts, graphs, matrices, and networks. And in the verification phase, the researchers made a conclusion. The conclusion was in a form of thick description. The conclusion was the answers of the researchers' problems that have been formulated.

\section{Results and Discussion Results}

The results of the study were obtained from students' responses to online English learning based on questionnaires distributed to 54 students of grade X SMK Bina Informatika Bintaro. The questionnaire was distributed from google form in form of link, accompanied by the respondents' consent. Based on students' perceptions toward online English learning, students define it as online learning in the form of access to materials, assignment collection, interaction, and discussion organized online.

In this aspect of online English learning, $41 \%$ of students agreed that online learning supports the process of teaching and learning during the Covid-19 pandemic, 22\% expressed

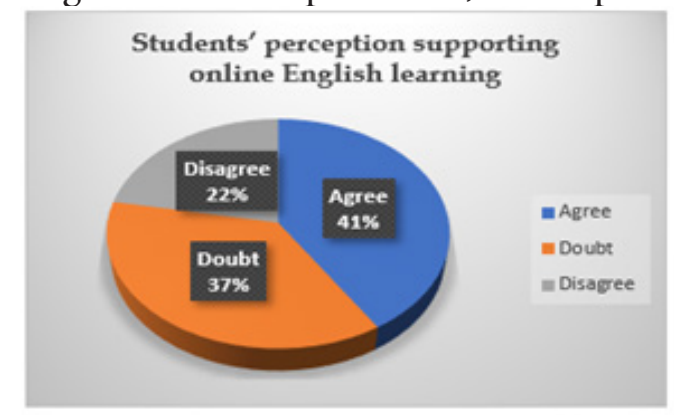

doubts, while $37 \%$ expressed disagree as shown in Figure 1.

Figure 1. Students' perception supporting online English learning

It be concluded that most students support online English learning during the Covid-19 outbreak. As in Mahyoob (2020) stated online learning during the Covid-19 outbreak is the best solution in regards of students, parents and teacher's viewpoint.
In addition to supporting online learning English during the pandemic, online learning also has an impact on the ease of access for students to the collection of assignments. In the ease of collecting assignments, $76 \%$ of students agreed more easily and the rest expressed disagree. This is influenced by the condition of the student's device and the availability of the network where the student is located because most students use mobile phones and laptops to collect assignments online. The platforms used by the teacher were zoom meeting, bismart, and WhatsApp.

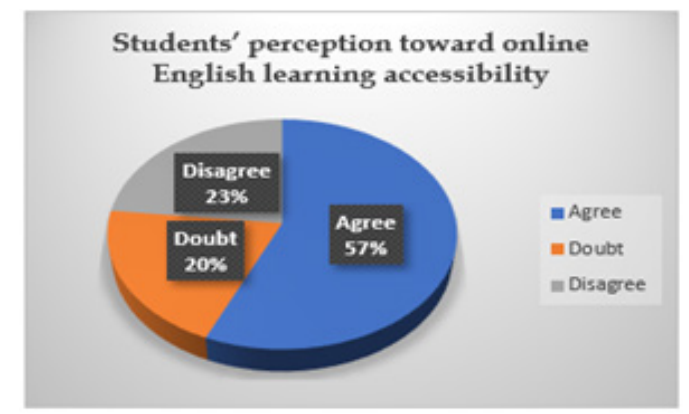

Figure 2. Students' perception toward online English learning accessibility

Meanwhile, in terms of usage, $57 \%$ of students agreed to have experienced obstacles in carrying out online English learning due to limited mobile phone facilities, limited internet constraints, and poor signaling problems. The remaining 23\% expressed disagree and 20\% expressed doubt. This is because the use of English learning online has not been intensive before. Students have problems that are due to their unfamiliarity in learning English online in the teaching and learning process. It is necessary to conduct regular socialization and training in order to learn English online to be more optimal in the learning process during the Covid-19 pandemic. 


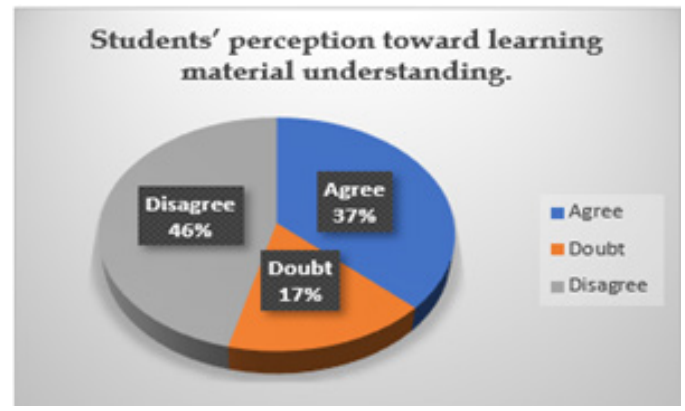

Figure 3. Students' perception toward learning material understanding

Low perception of obstacles to the implementation of online English Learning affects students' understanding of learning materials. Although the material can be accessed online, but with a lack of interaction and no guidance from the teacher, making the level of understanding of students low. This can be seen in Figure 3 where as many as $46 \%$ of students claim to be unable to understand English subject matter optimally, only 37\% stated that they can understand the material and $17 \%$ doubt.

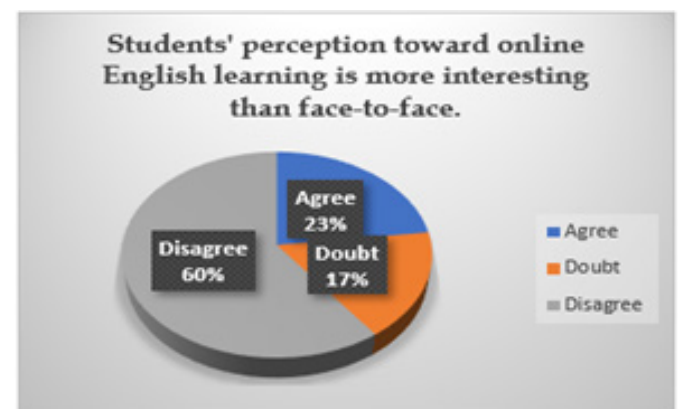

Figure 4. Students' perception toward online English learning thought as more interesting than face-to-

face

From Figure 4, most students disagree that online English learning is more interesting than face-to-face learning. A total of $60 \%$ disagreed and $27 \%$ agreed. While $17 \%$ expressed hesitation. The results of this study are in line with research conducted by Sadikin, \& Hamidah, (2020), that online learning increases students' interest and motivation but nevertheless they prefer to learn face-to-face. So, between this research finding and others research revealed that students prefer to have face-to-face learning.

\section{Discussion}

Referring to the data of the research results as outlined earlier, it can be known that in this study is illustrated how students' perception of the implementation of study from home policy in this case online English learning. This policy is not necessarily easily accepted by students, who are very familiar with the pattern of face-to-face learning during this time. This condition is strongly signaled due to the unpreparedness of various parties in carrying out their respective roles effectively. For example, about the readiness of parents who are expected to take a more role in replacing teachers guiding their children to learn at home many are unprepared, or even less concerned.

From the data analysis, most of students agree that online English learning is a way of learning during Covid-19 outbreak. They stated that learning materials are easy to access if done online. This is also in line with Chandrawati (2010) where access to online lesson materials becomes easier for students to access. Most students can make use of teaching materials independently (Sari, \& Priatna, 2020). In addition, English online learning during the Covid-19 pandemic is also quite in demand by students (Indrayana, \& Sadikin, 2020). Online English learning was also found to be able to make students become more independent in learning, this is in line with previous research that states that online learning can increase the independence of learning (Sobri, Nursaptini, \& Novitasari, 2020).

However, various impacts and challenges faced in carrying out the study from home process. Students' perception of obstacles in online English learning is the availability of inadequate facilities and infrastructure, differences in atmosphere when studying in class with home learning, as well as the tendency of online learning styles are visual and written. Students feel the burden on their internet quota, especially if they are in a signaldisrupted area. This finding is in line with 
the findings in previous studies where online learning experienced some obstacles similar to the findings of researchers in this study (Satrianingrum \& Prasetyo, 2021)

The next finding is that although some students say it is easy to learn online but this affects students' understanding in the learning materials. Although the material can be accessed online, but with a lack of interaction and no guidance from the teacher, making the level of understanding of students low. There are complexities in the implementation of online learning (Amalia, Sulistyo, \& Brata, 2020). This is in line with research from Putri (2015) states that low interaction between teachers and students will hinder the achievement of learning objectives.

Under ideal conditions, the distance learning will actually accommodate students' learning needs to grow talents and interests according to their level of education. Conceptually it can be realized if supported by educators' readiness, adequate curriculum, the availability of learning materials, and the help of secure devices and networks to ensure successful communication between students and educators. Arifa (2020) claimed that the current condition of distance learning cannot be called ideal because there are still various obstacles faced. These obstacles are also a challenge in the implementation of distance learning considering the implementation of distance learning is a necessity so that educational activities will continue to take place amid the present Covid-19 pandemic emergency.

Thus, it is important then to understand how the current student's perception of the policy of learning from home, by knowing the perception of the current student, it can be predicted that the student will act like in the learning process.

\section{Conclusion}

The results of the perception of most students expressed support for online English learning and agreed that it was easy to use, but it performed poorly in terms of ease of use, learning material comprehension, and interaction. So, $60 \%$ of students stated that online English learning was unattractive compared to face-to-face learning, $27 \%$ said it was still interesting, and the rest were hesitation. The research focused on teaching material or mode, student interaction, platform used by the teacher, and learning atmosphere that determines the perceptions of students for particular purposes in knowledge of English online learning and as the pedagogical implication, schools especially the English teachers must work hard to make forms of online learning acceptable to students. It needs continuous training and socialization so that the teaching and learning process is no longer disrupted during the pandemic.

\section{References}

Albiansyah, A., \& Hardiyanti, E. (2021). A Correlational Study Investigating Students' Activities in STAD Model and Their Interest in Learning English. International Journal of Educational Research \& Social Sciences, 1(1), 28-39.

Albiansyah, A., \& Minkhatunnakhriyah, M. (2021). The Needs Analysis of English in Bina Informatika Vocational High School of Bintaro as A Basis to Design English Teaching Materials. Edunesia: Jurnal Ilmiah Pendidikan, 2(1), 142-152.

Amalia, F., Sulistyo, R. T., \& Brata, A. H. (2020). Analisis Tingkat Penerimaan E-Learning Sebagai Alternatif Media Pembelajaran Pada Siswa SMK. SMATIKA JURNAL, 10(02), 41-47.

Arifa, F. N. (2020). Tantangan Pelaksanaan Kebijakan Belajar Dari Rumah Dalam Masa Darurat Covid-19. Jurnal Bidang Kesejahteraan Sosial, XII (7/I), 6.

Basyah, M. N., \& Yunus, M. (2016). Persepsi Siswa Terhadap Kesiapan Guru dalam Proses Pembelajaran (Studi 
Pada SMP Negeri 18 Banda Aceh). Jurnal Ilmiah Mahasiswa Pendidikan Kewarganegaraan, 1(1), 41-48.

Chandrawati, S. R. (2010). Pemamfaatan E-learning dalam Pembelajaran. Jurnal Cakrawala Kependidikan, 8(2).

Dornyei, Z. (2007). Research methods in Applied Linguistics. Oxford: Oxford University Press.

Harisah, A., \& Masiming, Z. (2008). Persepsi manusia terhadap tanda, simbol dan spasial. SMARTek, 6(1), 29-43.

Indrayana, B., \& Sadikin, A. (2020). Penerapan E-Learning Di Era Revolusi Industri 4.0 Untuk Menekan Penyebaran COVID19:(The Application of E-Learning in the Era of the Industrial Revolution 4.0 to Suppress the Spread of COVID-19). Indonesian Journal of Sport Science and Coaching, 2(1), 46-55.

Jamaluddin, D., Ratnasih, T., Gunawan, H., \& Paujiah, E. (2020). Pembelajaran daring masa pandemik Covid-19 pada calon guru: hambatan, solusi dan proyeksi. LP2M, 1-10.

Maris, S. (2020). Enam Kebijakan Kemendikbud dalam Masa Darurat Covid-19. https:// www.liputan6.com/news/read /4227701/ enamkebijakan- kemendikbud-dalammasa-darurat- covid-19

Mayang, A., Nurkamto, J., \& Drajati, N. A. (2019). The Needs Analysis of Senior High School Students' Reading Competence in National Examination: Students' Perspective. Eternal: English, Teaching, Learning, and Research Journal. 5(1). 130- 142.

Mahyoob, M. (2020). Challenges of e-Learning during the COVID-19 Pandemic Experienced by EFL Learners. Arab World English Journal (AWEJ), 11(4).

Mesran, O. K. S., Wijoyo, H., Putra, S. H., Watrianthos, R., Sinaga, R., Mardiana,
R., ... \& Indarto, S. L. (2020). Merdeka Kreatif di Era Pandemi Covid-19: Suatu Pengantar (Vol. 1). Green Press.

Miles, M.B. Hubarman and Saldana, J. (2014). Qualitative Data Analysis: A Methods Sourcebook. Third. Ed. United States of America: SAGE Publication, Inc. Edition. New York: State University of New York Genesco.

Muzakky, M., \& Albiansyah, A. (2021). EFL Teachers' Perception toward the Use of "Beyond" International Textbook. 15(2), 177-182.

Ong, S. W. X., Tan, Y. K., Chia, P. Y., Lee, T. H., Ng, O. T., Wong, M. S. Y., \& Marimuthu, K. (2020). Air, surface environmental, and personal protective equipment contamination by severe acute respiratory syndrome coronavirus 2 (SARS-CoV-2) from a symptomatic patient. Jama, 323(16), 1610-1612.

Puspitasari, K. A., \& Islam, S. (2018). Kesiapan belajar mandiri mahasiswa dan calon potensial mahasiswa pada pendidikan jarak jauh di Indonesia. Jurnal Pendidikan terbuka dan jarak jauh, 4(1), 11-22.

Putri, R. E. (2015, July). Model Interaksi dalam E-learning. In Seminar Nasional Informatika (SEMNASIF) (Vol. 1, No. 1).

Sadikin, A., \& Hamidah, A. (2020). Pembelajaran Daring di Tengah Wabah Covid-19:(Online Learning in the Middle of the Covid-19 Pandemic). Biodik, 6(2), 214-224.

Sari, R. M. M., \& Priatna, N. (2020). ModelModel Pembelajaran di Era Revolusi Industri 4.0 (E-Learning, M-Learning, AR-Learning dan VR-Learning). Biormatika: Jurnal ilmiah fakultas keguruan dan ilmu pendidikan, 6(1), 107-115.

Satrianingrum, A. P., \& Prasetyo, I. (2021). Persepsi Guru Dampak Pandemi 
Covid-19 terhadap Pelaksanaan Pembelajaran Daring di PAUD. Jurnal Obsesi: Jurnal Pendidikan Anak Usia Dini, 5(1), 633-640.

Sobri, M., Nursaptini, N., \& Novitasari, S. (2020). Mewujudkan kemandirian belajar melalui pembelajaran berbasis daring diperguruan tinggi pada era industri 4.0. Jurnal Pendidikan Glasser, 4(1), 64-71.

Stambough, J. B., Curtin, B. M., Gililland, J. M., Guild III, G. N., Kain, M. S., Karas, V., \& Moskal, J. T. (2020). The past, present, and future of orthopedic education: lessons learned from the COVID-19 pandemic. The Journal of arthroplasty, 35(7), S60-S64.

Sobron, A. N., \& Bayu, R. (2019). Persepsi siswa dalam studi pengaruh daring learning terhadap minat belajar ipa. SCAFFOLDING: Jurnal Pendidikan Islam Dan Multikulturalisme, 1(2), 3038.

Suwarto, S., \& Fajri, H. (2018). Persepsi Orang Tua Terhadap Proses Bimbingan Belajar Anak Di Rumah. SAP (Susunan Artikel Pendidikan), 3(1).

Zhafira, N. H., Ertika, Y., \& Chairiyaton, C. (2020). Persepsi mahasiswa terhadap perkuliahan daring sebagai sarana pembelajaran. Jurnal Bisnis Dan Kajian Strategi Manajemen, 4(1), 37 - 45 